\title{
Evaluation of the Potential Fetotoxic Effects of Tramadol in Female Pregnant Mice
}

\author{
Buthina A. Abdullah* \\ Pharmacology Department, Collage of Veterinary Medicine, University of Tikrit, Iraq \\ Article History: Received: 2/12/2017 Received in revised form: 16/1/2018 Accepted: 28/1/2018
}

\begin{abstract}
Tramadol is an opioid analgesic that is used extensively as antinociceptive. This study was designed to investigate the fetotoxic effect of tramadol in female pregnant mice. Fourteen pregnant mice were used in the present study, that were divided two groups, group A, was administered Tramadol by a single daily dose (20 $\mathrm{mg} \mid \mathrm{kg}$ B.W.) IIP. 1- 7day of gestation. Group $\mathrm{B}$ pregnant mice was kept as a control group, received $1 \mathrm{ml}$ normal saline $0.9 \%$. After 15 day (organogenesis period) pregnant mice were euthanized and the results revealed that, all the pregnant mice treated with Tramadol, have resorbed feti while the non treated group have normal feti in their uterine horns. Ovaries, corpus lutum, oviduct and uterus were incised and processed for histpathological investigation. The obtained findings of present study revealed that Tramadol at a dose $20 \mathrm{mg} / \mathrm{kg}$ exerts fetotoxic effects in mice when given during early stage of pregnancy.
\end{abstract}

Keywords: Tramadol, Pregnant, Fetotoxic, Mice.

\section{Introduction}

Tramadol is a centrally active synthetic opioid analgesic recommended for the management of acute and chronic pain of moderate to severe intensity associated with a variety of diseases or problems including, diabetic neuropathy, neuropathic pain, osteoarthritis, and fibromyalgia [1]. The mode of action is not completely reported; however, two acceptable complementary mechanisms are the inhibition of reuptake of noradrenaline and serotonin and binding opioid receptors [2]. Most reports mention that the mechanism of tramadol analgesic action is complex. It's analgesic activity and other clinical effects are result from opioid and non-opioid mechanisms [3]. Tramadol has been reported to be absorbed more rapidly than morphine by about 95-100\% from the small intestine and reached the highest peak after the 5 hours as highly distributed [4]. Long- term administration of tramadol might lead to the accumulation of toxic metabolites in the body, increase the risk for its toxic kinetic effects and/ or decrease the clearance of tramadol, thus increasing its potential for toxicity [5]. The main concern about this drug is that persistent use during pregnancy might lead to dependence and tolerance in the mother with resultant neonatal abstinence syndrome [6]. Tramadol is of limited use in pregnancies and has not been linked to elevated risk of major or minor malformations. Moreover, there are no evidence of teratogenic effects of Tramadol reported by reproductive studies [7]. According to the manufacturer's prescribing information, shown in experimental animal, Tramadol is embryotoxic and fetotoxic in a dose of $120 \mathrm{mg} / \mathrm{kg}$ or $360 \mathrm{mg} / \mathrm{m}^{2}$ in mice, $\geq 25$ $\mathrm{mg} / \mathrm{kg}$ or $150 \mathrm{mg} / \mathrm{m}^{2}$ in rats and $\geq 75 \mathrm{mg} / \mathrm{kg}$ or $900 \mathrm{mg} / \mathrm{m}^{2}$ in rabbits [8]. The aim of this study was to evaluate the fetotoxic effects related to the use of Tramadol in female pregnant mice.

\section{Materials and methods}

\section{Tramadol}

Tramadol was obtained from the traditional medicine Tramadol hydrochloride $50 \mathrm{mg} / \mathrm{ml}$ solution for injection.

\section{Experimental Animals}

The experiments were performed on fourteen mature females and 5 adult males for mating (Swiss albino mice, 8-12 Weeks old and 25-30 g weight). Mice were obtained from the Faculty of Veterinary Medicine; Tikrit University. They were maintained under a controlled light cycle $(14 \mathrm{~h}$ light and $10 \mathrm{~h}$ dark) with a temperature range of $22-24^{\circ} \mathrm{C}$ and with free access to food and water. Animals were housed in plastic cages measuring $28 \times 15 \times 14 \mathrm{~cm}$. 


\section{Detection of Estrous Cycle Phase}

Before administration, the sexually mature females were followed up by daily vaginal smears examination for 14 days to establish their normal pattern of cyclical activity [9]. Females with proestrus stage were caged overnight (4 females with 1 male). Observation of vaginal plug on the next morning at 8:00 a.m indicated successful mating, and the number of days were counted with day of plug designated day one.

\section{Smear biopsy technique}

The tip of cotton bud was dampened in distilled water, inserted into the vagina, rotated to collect a biopsy and rolled on the glass surface of a slide to transfer adherent cells. The smears were stained with methylene blue. Therefore, in order to establish the stages of the estrous cycle, cyclical changes of the vaginal epithelium were monitored by a simple smear biopsy technique [9].

\section{Experimental Groups}

The pregnant females were divided into two groups; the first group (Group A) included 10 female pregnant mice treated with Tramadol during the $7^{\text {th }}$ day of gestation period. These mice received intra peritoneal injections of 20 $\mathrm{mg} / \mathrm{kg}$. The second group (Group B) included 4 female pregnant untreated mice (control).

At the end of the two weeks of gestation, mice from pregnant group and control were anesthetized and euthansized. The uteri, ovaries, and oviducts were removed for morphological and histopathological exanimation. The tissues were fixed in $10 \%$ neutral buffered formalin; 7-micron thickness paraffin sections were cut and stained with hematoxylin-eosin and photographed using digital camera connected to computer [10].

\section{Results}

The basic constituents of the vaginal smear were nucleated epithelial cells, cornified cells and leukocytes (Figure 1).
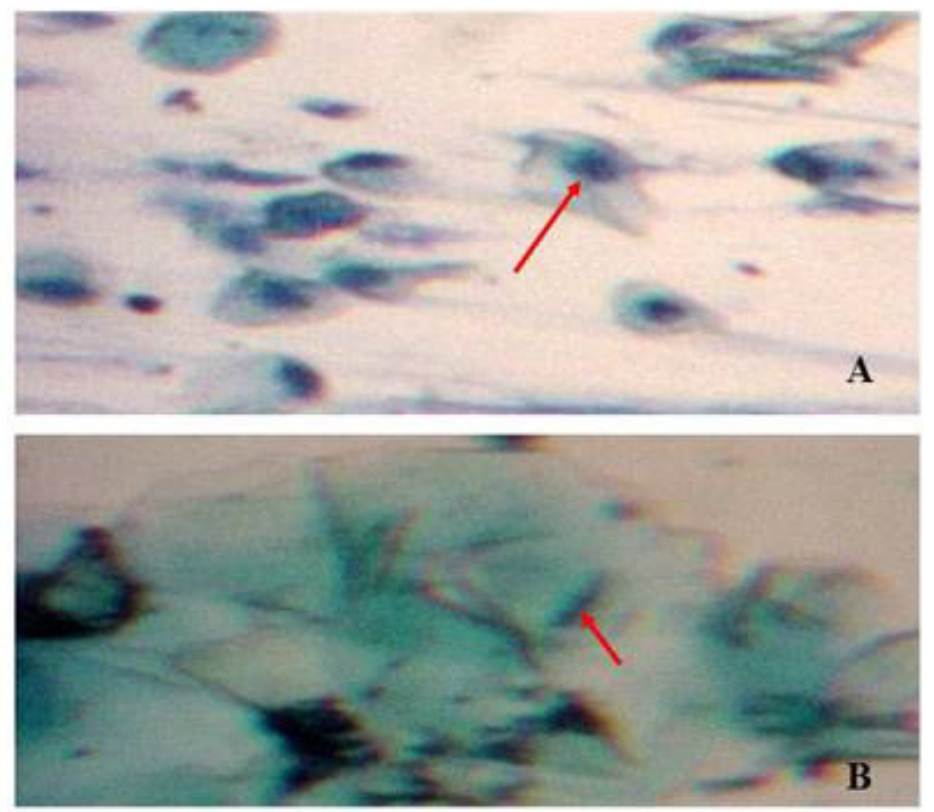

Figure 1: A: Proestrus phase shows nucleated epithelial cells, methylene blue stain (X40). B; Large cornified cells (red arrow) with degenerated nuclei, methylene blue $(\mathrm{X} 40)$. 
Morphological examination during the present study showed that all the pregnant mice treated with $20 \mathrm{mg} / \mathrm{kg}$ body weight with Tramadol demonstrated resorbed fetuses on day 15 (Figure 2A) while Uterine horns with normal fetuses from control mice at day 15 (Figure 2B). Normal uterine horn without gestation is obvious in Figure 2C.

Histopathological examination of uterus, ovaries and oviducts of the treated pregnant mice treated with $20 \mathrm{mg} / \mathrm{kg}$ body weight (group A) showed several histopathological changes. In the ovaries, the cortex had infiltration of inflammation cell (Figure 3A), the ovarian follicles were present in different stage. Degeneration of the ova in these follicles, and congestion of blood vessels in the medulla were observed. The cortex had degeneration of the most follicles with infiltration of the inflammatory cells (Figures 3B,C).
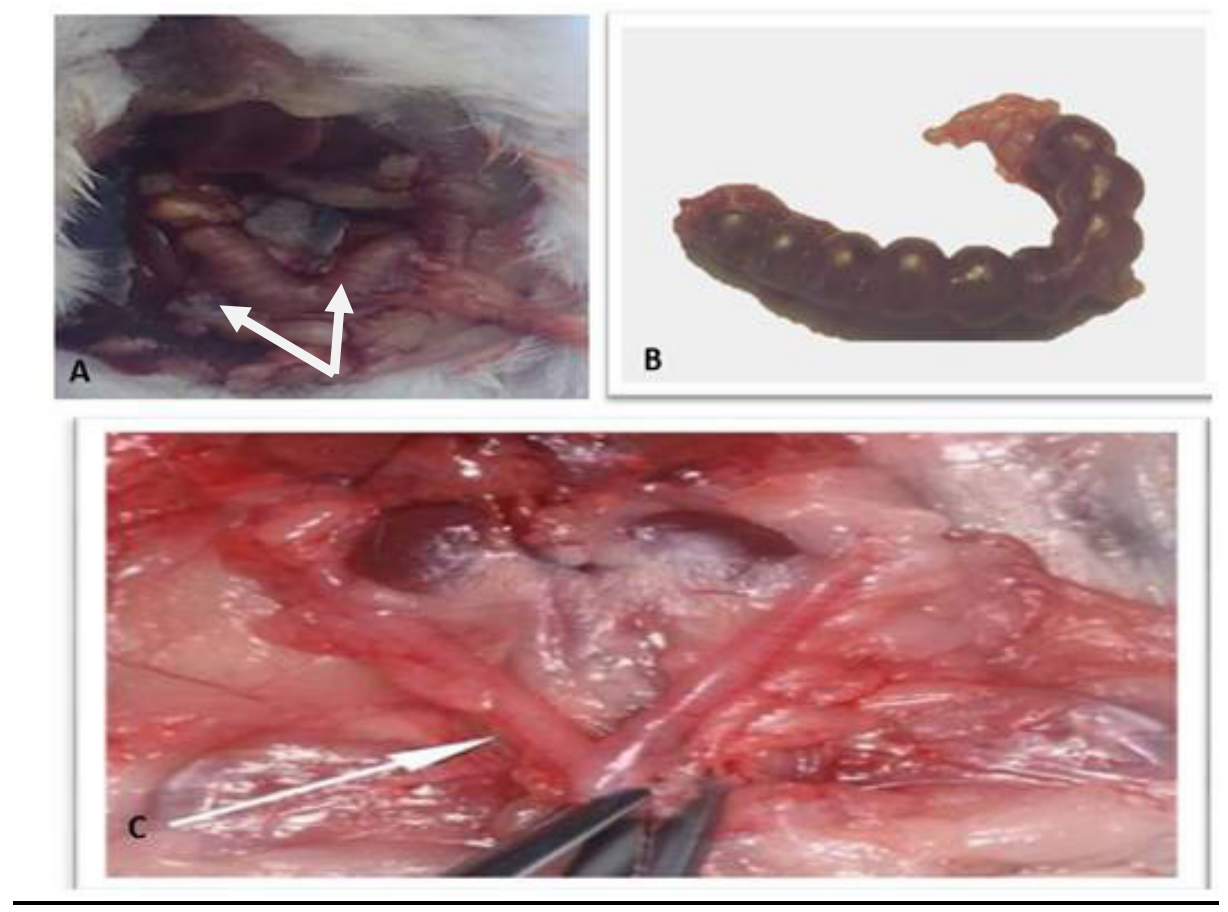

Figure 2: A: A pregnant female from tramadol treated mice (group A) with a dose (20 mg) at day 15, showing the corpus lutum, and vestige of resorbed fetuses. B: uterine horns with its fetuses from control mice (group B), C: Normal uterus without gestation. 

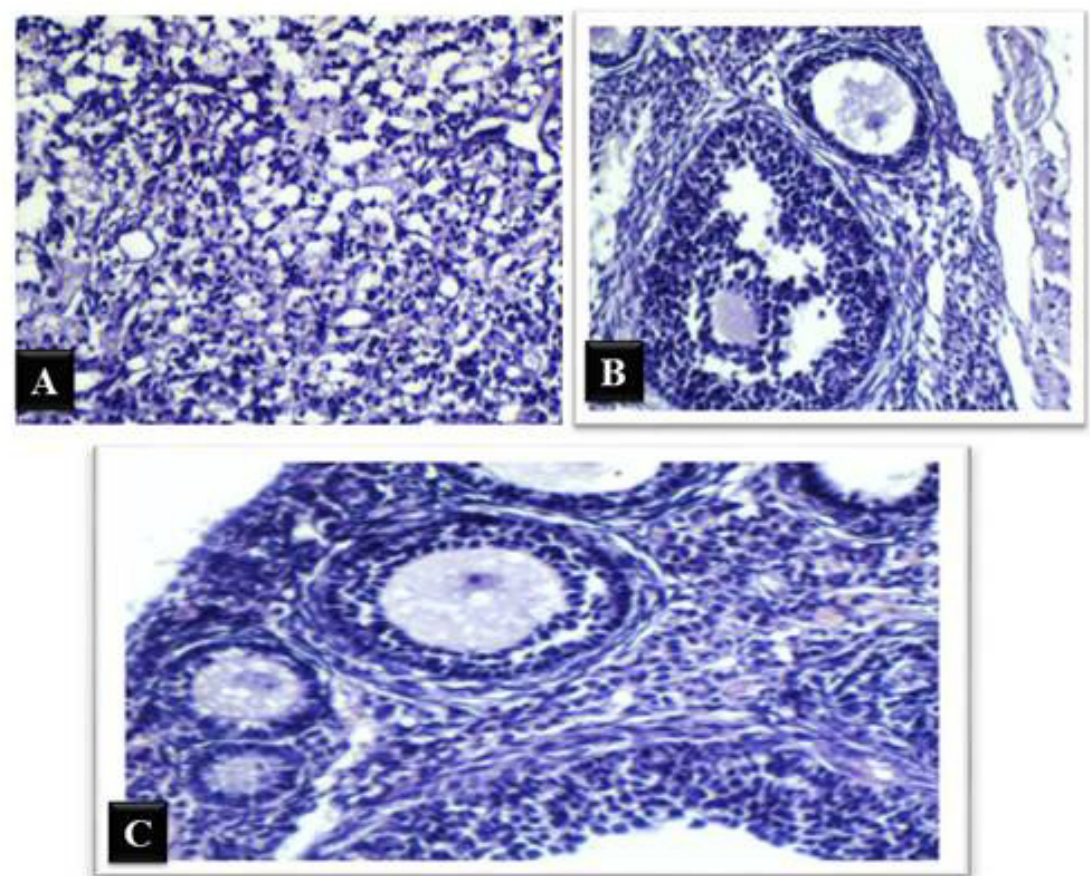

Figure 3: A-Cross section through ovary from pregnant mice, showing the cortex of ovary that had infiltration of inflammation cell $(\mathrm{X100} \mathrm{H \& E})$. B: Degeneration of the ova in the Graffian follicle with infiltration of the inflammatory cell $(X 100 \mathrm{H \& E})$. C: Congestion of blood vessels in the medulla and the ovarian follicles were present in different stages.(X100H\&E).

The uteri showed simple columnar epithelial cells in the endometrium which was degenerated in certain places (Figure 4A). Lamina properia was infiltrated with macrophages with other inflammatory cells. The myometrium is formed of bundles of smooth muscle which appeared loosing
(Figure 4B) and the uterine gland in this area contained degeneration in cells (Figure 4C).

The mucosal folds of the oviducts contained regions with epithelial cells which appeared degenerated (Figure 5) and other cells appeared desquamated epithelial cell in the lumen of oviducts. 


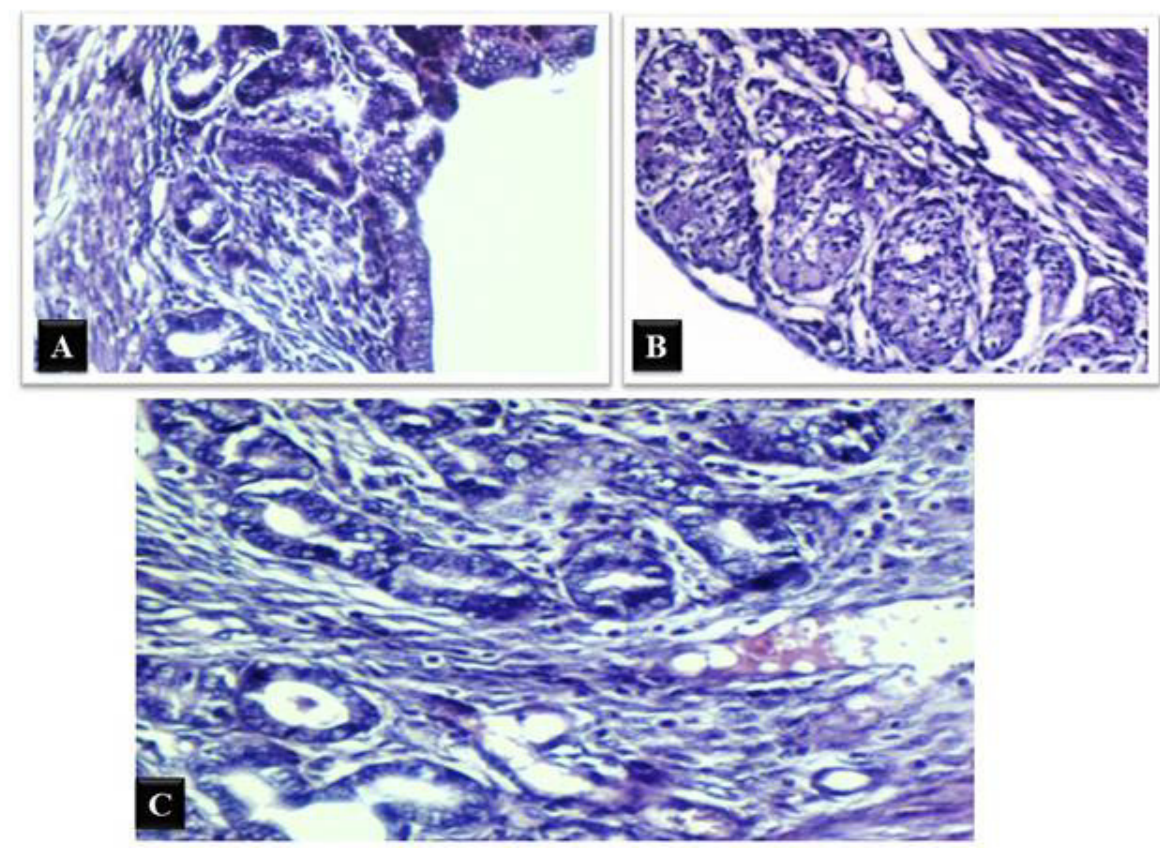

Figure 4: A-Cross section through uterus at day15 from pregnant mice, showing Endometrium had simple columnar epithelial cells which was degenerated $(\mathrm{X} 400 \mathrm{H \& E})$. B: Lamina properia was infiltration of macrophage\& The myometrium is formed by bundles of smooth muscle which appeared loose (X400 H\&E). C: Inflammatory cells. The uterine gland in this area was containing degeneration in cells (X400 H\&E).

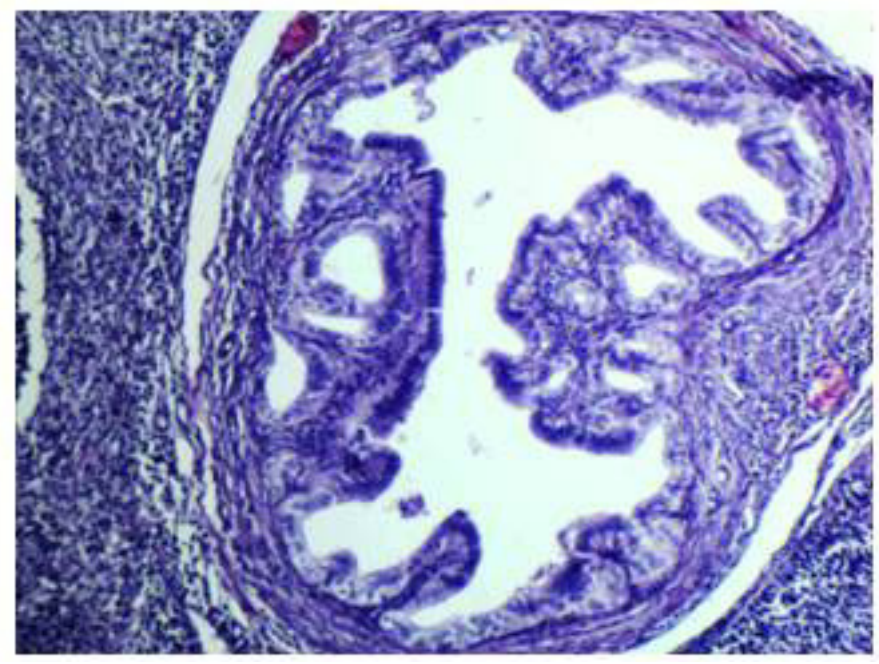

Figure 5: Cross section through oviduct from pregnant mice, show the mucosal fold with degenerated epithelial cells (X100 H\&E).

\section{Discussion}

Tramadol is a drug used for treatment of moderate-to-severe pain. It is a synthetic centrally acting opioid analgesic. Its weak opioid receptor agonist by inhibiting uptake of norepinephrine and serotonin therefore produces analgesia. Tramadol abusing is very serious problem in women during pregnancy because the drug threatens pregnant women health, and the healthy development of their children [11]. The pregnant mice which have received (20 mg/kg body weight.) of Tramadol orally showed loss of all fetuses. This could be explained by elevation of drug levels. Tramadol has been reported to cross the placental barrier, through the umbilical vein to maternal vein serum. Prolonged maternal use 
of opioid analgesics during pregnancy may result in fetal death [12].

The observed findings revealed resorbed fetuses after received tramadol in pregnant mice because opioid drugs can easily cross blood-brain barrier and placental barrier. In addition, agents can pass into breast milk of nursing mothers and these drugs can affect a developing infant even postnatal. While women who abuse drugs have irregular menstrual cycle [13], the opioid-induced inhibition of uterine cell proliferation which was mediated mainly by the mu opiate receptor [14]. Drug abuse during pregnancy can lead to insufficient nutrition of both mother and fetus [15]. Reduced supply of nutrients to the fetus causes vasoconstrictor effect on the utero-placental blood supply leading to malnutrition or hypoxia on the developing fetus [16]. Thus, increasing the risk of abortion or stillborn fetuses [17], drugs is eliminated more slowly in infant than in adults and has very limited degradation in the liver of newborns [18]. In agreement with clinical works, the experimental studies [19] showed that rat mother who received drugs (opioids) during pregnancy, displayed decreased behavior of mother toward their pups and healthy development of their pups may also alter. Drug exposure during prenatal period will impair the postnatal development of rat pups and until adulthood that may persist. Therefore, women who given analgesic medications during pregnancy (the first trimester when organogenesis is occurring), have a potential fetal harm [20].

\section{Conclusion}

The present study concluded that, when pregnant mice were treated with Tramadol at a dose of $20 \mathrm{mg} / \mathrm{kg}$ body weight leads to fetotoxicity.

\section{Conflict of interest}

Authors declare that they don't have any conflict of interest.

\section{References}

[1] Lamont, L. A. and Mathews, K. A. (2007): Opioids, nonsteroidal anti-inflammatories, and analgesic adjuvants. Lumb \& Jones' veterinary anesthesia and analgesia, 4, 241-271.
[2] Raffa, R.B.; Friderichs, E.; Reimann, W.; Shank, R.P.; Codd, E.E. and Vaught, J.L. (1992): Opioid and nonopioid components independently contribute to the mechanism of action of tramadol, an 'atypical' opioid analgesic. J Pharmacol Exp Ther, 260(1):275-285.

[3] Lintz, W.; Erlacin, S.; Frankus, E. and Uragg, H. (1981): Biotransformation of tramadol in man and animal (author's transl). Arzneimittel

Forschung, 31(11):1932-1943.

[4] van der Marel, C.D.; Anderson, B.J.; van Lingen, R.A.; Holford, N.H.; Pluim, M.A.; Jansman, F.G.; van den Anker, J.N. and Tibboel, D. (2003): Paracetamol and metabolite pharmacokinetics in infants. Euro J Clin Pharmacol, 59(3):243251.

[5] Shadnia, S.; Soltaninejad, K.; Heydari, K.; Sasanian, G. and Abdollahi, M. (2008): Tramadol intoxication: a review of 114 cases. Hum Exp Toxicol, 27(3): 201-205.

[6]Van der Heijden, B.J.; Carlus, C.; Narcy, F.; Bavoux, F.; Delezoide, A.L. andGubler, M.C. (1994): Persistent anuria, neonatal death, and renal microcystic lesions after prenatal exposure to indomethacin. Am J Obstet Gynecol,171(3):617-623.

[7] Kaufman, D. W. (1977): Birth defects and drugs during pregnancy. Littleton, MA: Publishing Sciences Group.

[8] Bloor, M.; Paech, M.J. and Kaye, R. (2012): Tramadol in pregnancy and lactation. Int J Obstetric Anesthesia, 21(2): 163-67.

[9] Snell, G.D.; Fekete, E.; Hummel, K.P. and Law, L.W. (1940): The relation of mating, ovulation and estrus smear in the house mouse to time of day. Anal Rec,76(1):39-54.

[10]Bancroft, J.D. and Gamble, M. eds., (2008): Theory and practice of histological techniques. Elsevier Health Sciences.

[11]Hrubá, L.; Schutová, B.; Šlamberová, R.; Pometlová, M. and Rokyta, R. (2009): Effect of methamphetamine exposure and cross-fostering on sensorimotor 
development of male and female rat pups. Developmental

psychobiology, 51(1):73-83.

[12]Slamberova, R. (2012): Drugs in pregnancy: the effects on mother and her progeny. Physiol Res, 61: S123.

[13] Center for Substance Abuse Treatment. (2015). Substance abuse treatment: Addressing the specific needs of women. Treatment Improvement Protocol (TIP) Series, No. 51. HHS Publication No. (SMA) 15-4426. Rockville, MD: Substance Abuse and Mental Health Services Administration.

[14].Fanning, R.A.; McMorrow, J.P.; Campion, D.P.; Carey, M.F. and O'connor, J.J. (2013) Opioid mediated activity and expression of $m u$ and delta opioid receptors in isolated human term non-labouring myometrium. Eur $\mathbf{J}$ Pharmacol, 698(1-3): 170-177

[15]Desai, R.J.; Hernandez-Diaz, S.; Bateman, B.T. and Huybrechts, K.F. (2014): Increase in prescription opioid use during pregnancy among Medicaid-enrolled women. Obstet Gynecol, 123(5):9971002.

[16]Johnson, J.L. and Leff, M. (1999): Children of substance abusers: overview of research findings. Pediatrics, 103 (Suppl 2): 1085-1099,

[17]Karch, S.B. (2002): Opiates. In: Karch's Pathology of Drug Abuse. SB KARCH (ed), CRC Press, Boca Raton, pp 313456.

[18]Pritham, U.A.; Paul, J.A. and Hayes, M.J. (2012): Opioid dependency in pregnancy and length of stay for neonatal abstinence syndrome. J Obstet Gynecol Neonatal Nurs, 41(2):180-190\

[19]- Pometlová, M.; Hrubá, L.; Šlamberová, R. and Rokyta, R. (2009): Crossfostering effect on postnatal development of rat pups exposed to methamphetamine during gestation and preweaning periods. Int J Dev Neurosci, 27(2):149155.

[20]Medical Practice Guidelines, Hunter Integrated Pain Service, Updated January 2006 